\title{
Autologous Melanoma Lysate-Pulsed Autologous Dendritic Cell Vaccine
}

National Cancer Institute

\section{Source}

National Cancer Institute. Autologous Melanoma Lysate-Pulsed Autologous Dendritic

Cell Vaccine. NCI Thesaurus. Code C90571.

A cell-based cancer vaccine composed of autologous dendritic cells (DCs) pulsed with lysate from autologous melanoma cells containing tumor associated antigens (TAAs) with potential immunostimulatory and antineoplastic activities. Upon administration, autologous melanoma lysate-pulsed autologous DC vaccine may stimulate the immune system to mount anti-tumoral cytotoxic $T$ lymphocyte $(\mathrm{CT} L)$ and antibody responses against melanoma cells, which may result in melanoma cell lysis. 